\title{
Salinity from space unlocks satellite-based assessment of ocean acidification
}

\author{
Land Peter E. ${ }^{1, *}$, Shutler Jamie D. ${ }^{2}$, Findlay Helen ${ }^{1}$, Girard-Ardhuin Fanny ${ }^{3}$, Sabia Roberto ${ }^{4}$, \\ Reul Nicolas ${ }^{3}$, Piolle Jean-Francois ${ }^{3}$, Chapron Bertrand ${ }^{3}$, Quilfen Yves ${ }^{3}$, Salisbury Joseph E. ${ }^{5}$, \\ Vandemark Douglas ${ }^{5}$, Bellerby Richard ${ }^{6}$, Bhadury Punyasloke ${ }^{7}$
}

${ }^{1}$ Plymouth Marine Laboratory, Prospect Place, The Hoe, Plymouth PL1 3DH, UK

2 University of Exeter, Penryn Campus, Cornwall. TR10 9FE, UK

${ }^{3}$ Institut Francais Recherche Pour L'Exploitation de la Mer, Pointe du Diable, 29280 Plouzané, France

${ }^{4}$ Telespazio-Vega UK for European Space Agency (ESA), ESTEC, Noordwijk, the Netherlands

${ }^{5}$ Ocean Processes Analysis Laboratory, University of New Hampshire, Durham, NH 3824, USA

${ }^{6}$ Norwegian Institute for Water Research, Thormøhlensgate 53 D, N-5006 Bergen, Norway

${ }^{7}$ Department of Biological Sciences, Indian Institute of Science Education and Research-Kolkata, Mohanpur - 741 246, West Bengal, India

* Corresponding author : Peter E. Land, email address : peland@pml.ac.uk

\begin{abstract}
:
Approximately a quarter of the carbon dioxide (CO2) that we emit into the atmosphere is absorbed by the ocean. This oceanic uptake of $\mathrm{CO} 2$ leads to a change in marine carbonate chemistry resulting in a decrease of seawater $\mathrm{pH}$ and carbonate ion concentration, a process commonly called 'Ocean Acidification'. Salinity data are key for assessing the marine carbonate system, and new space-based salinity measurements will enable the development of novel space-based ocean acidification assessment. Recent studies have highlighted the need to develop new in situ technology for monitoring ocean acidification, but the potential capabilities of space-based measurements remain largely untapped. Routine measurements from space can provide quasi-synoptic, reproducible data for investigating processes on global scales; they may also be the most efficient way to monitor the ocean surface. As the carbon cycle is dominantly controlled by the balance between the biological and solubility carbon pumps, innovative methods to exploit existing satellite sea surface temperature and ocean color, and new satellite sea surface salinity measurements, are needed and will enable frequent assessment of ocean acidification parameters over large spatial scales.
\end{abstract}




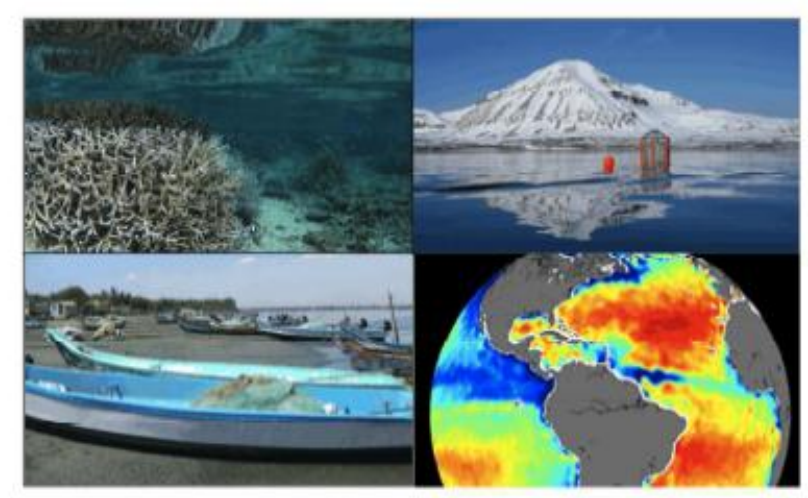

Abstract artwork

Note to editor (top left to bottom right): Tropical coral; Svalbard in the Barents Sea;

Beach in India on the coast of the Bay of Bengal; Salinity from space (SMOS)

showing the Amazon plume. All images taken by PML staff and used with

permission.

\section{Introduction}

Each year global emissions of carbon dioxide $\left(\mathrm{CO}_{2}\right)$ into our atmosphere continue to rise. These increasing atmospheric concentrations cause a net influx of $\mathrm{CO}_{2}$ into the oceans. Of the roughly 36 billion metric tons of $\mathrm{CO}_{2}$ that is emitted into our atmosphere each year, approximately a quarter transfers into the oceans ${ }^{1}$. This $\mathrm{CO}_{2}$ addition has caused a shift in the seawater carbonate system, termed Ocean Acidification (OA), resulting in a $26 \%$ increase in acidity and a $16 \%$ decrease in carbonate ion concentration since the industrial revolution ${ }^{2}$. Recently there has been recognition that this acidification is not occurring uniformly across the global oceans, with some regions acidifying faster than others ${ }^{3,4}$. However, the overall cause of OA remains consistent: the addition of $\mathrm{CO}_{2}$ into the oceans, and as such, it remains a global issue. Continual emissions of $\mathrm{CO}_{2}$ into the atmosphere over the next century will decrease average surface ocean $\mathrm{pH}$ to levels which will be deleterious to many marine ecosystems and the services they provide ${ }^{5}$.

While the seawater carbonate system is relatively complex, two parameters have been suggested as pertinent to the monitoring and assessment of $O A$ through time and 
space. These are $\mathrm{pH}$ (the measure of acidity) and calcium carbonate $\left(\mathrm{CaCO}_{3}\right)$ mineral saturation state, with aragonite generally considered to be an important $\mathrm{CaCO}_{3}$ mineral to be monitored because of its relevance to marine organisms (e.g. corals) and its relative solubility. Thermodynamically, $\mathrm{CaCO}_{3}$ is stable when the saturation state (an index of the concentrations of calcium and carbonate ions) is greater than one and becomes unstable when seawater becomes undersaturated with these ions (saturation $<1)$. While there is significant variability between types of organism, there is ample experimental evidence that many calcifying organisms are sensitive to $\mathrm{OA}^{6}$, and that thresholds exist below which some organisms become stressed and their well-being and existence becomes threatened ${ }^{7}$. Increasingly evidence suggests that the physiology and behaviour of calcifying and non-calcifying organisms can be impacted by increasing $\mathrm{OA}^{8}$, with cascading effects on the food chain and protein supply for humans ${ }^{3}$, and alterations to the functioning of ecosystems and feedbacks to our climate $^{9}$.

In 2012 the Global Ocean Acidification Observing Network (GOA-ON, www.goaon.org) was formed in an attempt to bring together expertise, datasets and resources to improve OA monitoring. At present, OA monitoring efforts are dominated by in situ observations from moorings, ships and associated platforms. Whilst key to any monitoring campaign, in situ data tend to be spatially sparse, especially in inhospitable regions, and so on their own are unlikely to provide a comprehensive, robust and cost effective solution to global OA monitoring. The need to monitor and study large areas of the Earth has driven the development of satellite-based sensors. 
79 Increasingly, as in situ data accumulate, attempts are being made to use in situ

80 hydrographic data ${ }^{10-13}$ and/or remotely-sensed data ${ }^{14,15}$ to provide proxies and

81 indicators for the condition of the carbonate system, enabling data gaps to be filled in

82 both space and time. The increased availability of in situ data creates a substantial

83 dataset to develop and test the capabilities of satellite-derived products, and we

84 suggest that the recent availability of satellite-based salinity measurements provides

85 new key insights for studying and assessing OA from space.

86

87

88

89

90

91

92

93

\section{The complexities of the carbonate system}

The oceanic carbonate system can be understood and probed through four key parameters: total alkalinity (TA), dissolved inorganic carbon (DIC), $\mathrm{pH}$ and fugacity of $\mathrm{CO}_{2}\left(\mathrm{f}_{\mathrm{CO} 2}\right)$. The latter may be replaced with the related partial pressure of $\mathrm{CO}_{2}$, $\mathrm{p}_{\mathrm{CO} 2}$, from which $\mathrm{f}_{\mathrm{CO} 2}$ can be calculated, and the two are often used interchangeably. In principle, knowledge of any two of these four is sufficient to solve the carbonate system equations. However, over-determination, the process of measuring at least three parameters, is advantageous.

The relationships between the different carbonate system parameters are fundamentally driven by thermodynamics, hence influenced by temperature and pressure, and knowing these is fundamental for calculating the carbonate system as a whole ${ }^{16}$. Water temperature is the major controller of the solubility of $\mathrm{CO}_{2}{ }^{17}$, so seasonal changes in sea temperature can, depending on the region, be significant for driving changes in $\mathrm{f}_{\mathrm{CO} 2}$ (and consequently $\mathrm{DIC}$ and $\mathrm{pH}$ ). Salinity affects the coefficients of the carbonate system equations. Hence to solve the equations, it is 
103 necessary to estimate temperature, salinity and pressure along with carbonate

104 parameters.

105

106 The ratio between ions (the constituents of salinity) will tend to remain constant

107 anywhere in the global oceans, resulting in a strong relationship between TA and

108 salinity ${ }^{18}$. Unfortunately, a universal relationship between TA and salinity does not

109 apply in certain regions, for instance in areas influenced by freshwater outflows from

110 rivers $^{7}$, or areas where calcification and/or $\mathrm{CaCO}_{3}$ dissolution occurs, such as where

111 calcifying plankton are prevalent ${ }^{19}$. In these regions, it is therefore critical to gain

112 additional local knowledge. For example, different rivers will have different ionic

113 concentrations (and therefore different TA concentrations) depending on the

114 surrounding geology and hydrology.

116 For DIC, $\mathrm{f}_{\mathrm{CO} 2}$ (or $\mathrm{p}_{\mathrm{CO} 2}$ ) and $\mathrm{pH}$, the other important process is biological activity ${ }^{19}$.

117 Removal or addition of $\mathrm{CO}_{2}$ by plankton photosynthesis or respiration can be a

118 significant component of the seasonal signal ${ }^{20}$. Biological activity, in turn, is driven

119 by factors such as nutrient dynamics and light conditions, which again are regionally

120 specific. Measurements of chlorophyll (a proxy for biomass) and/or oxygen

121 concentration can be useful for interpreting the biological component of the carbon

122 signal.

123

124 The combination of these processes means that it is extremely challenging to produce

125 a global relationship between any component of the carbonate system and its drivers.

126 To enable us to understand these dynamics, extrapolation from collected data points

127 to the global ocean is needed, and along with model predictions, empirical 
128 relationships and datasets are important and need to be studied and developed. OA

129 needs to be assessed using these relationships on a global scale, but regional

130 complexities, particularly where riverine and coastal processes dominate ${ }^{21,22}$, cause

131 significant challenges for global empirical relationships.

\section{Current in situ approaches and challenges}

134

135 Laboratory measurements are the gold standard for assessing the carbonate system in

136 seawater, with accuracy far in excess of that achievable from satellites. ${ }^{23-25}$ However,

137 research vessel time is expensive and limited in coverage, so autonomous in situ

138 instruments are also deployed, e.g. on buoys, with less accuracy ${ }^{26}$. A notable example

139 is the Argo network of over 3000 drifters, which measure temperature and salinity

140 throughout the deep global ocean. Interpolation of Argo data is much less challenging

141 than for most in situ measurements. Argo is the closest in situ data have come to the

142 global, synoptic measurements possible with satellites, but shallow or enclosed seas

143 are not represented (there are as yet no Argo instruments in the open Arctic Ocean).

144 Table 1 lists more examples. Of the four key parameters, only $\mathrm{f}_{\mathrm{CO} 2}$ (or $\mathrm{p}_{\mathrm{CO} 2}$ ) and $\mathrm{pH}$

145 are routinely monitored in situ. As yet there are limited capabilities to measure DIC

146 and TA autonomously, hence these parameters must be measured either in a ship-

147 based laboratory or on land.

148

\begin{tabular}{|l|l|l|l|l|}
\hline $\begin{array}{l}\text { Dataset name and } \\
\text { reference }\end{array}$ & $\begin{array}{l}\text { Temporal } \\
\text { period }\end{array}$ & $\begin{array}{l}\text { Geographic } \\
\text { location }\end{array}$ & Variables & $\begin{array}{l}\text { No. of data } \\
\text { points }\end{array}$ \\
\hline SOCAT v2.0 & $1968-2011$ & Global* & $\mathrm{fCO}_{2}, \mathrm{SSS}, \mathrm{SST}$ & $6,000,000+$ \\
\hline LDEO v2012 & 1980 -present & Global* & $\mathrm{pCO}_{2}, \mathrm{SSS}, \mathrm{SST}$ & $6,000,000+$ \\
\hline GLODAP $^{29}$ & $1970-2000$ & Global & $\begin{array}{l}\text { TA, DIC, SSS, SST, } \\
\text { Nitrate }\end{array}$ & $10,000+$ \\
\hline
\end{tabular}




\begin{tabular}{|c|c|c|c|c|}
\hline CARINA AMS v1.230 & $1980-2006$ & Arctic & TA, DIC, SSS, SST & $1500+$ \\
\hline CARINA ATL v1.031 & & Atlantic & & \\
\hline CARINA SO v1.1.12 & & Southern Ocean & & \\
\hline $\mathrm{AMT}^{33}$ & 1995-present & Atlantic & $\mathrm{pCO}_{2 \mathrm{w}}, \mathrm{SSS}, \mathrm{SST}, \mathrm{Chl}, \mathrm{pH}$ & $1000+$ \\
\hline NIVA Ferrybox $^{34}$ & 2008-present & Arctic & $\begin{array}{l}\mathrm{pCO}_{2 \mathrm{w}}, \mathrm{TA}, \mathrm{DIC}, \mathrm{SSS}, \\
\mathrm{SST}\end{array}$ & $1000+$ \\
\hline OWS Mike $^{35}$ & 1948-2009 & Arctic & TA, DIC, SSS, SST, Chl & $1000+$ \\
\hline $\begin{array}{l}\text { RAMA Moored buoy } \\
\text { array }^{36}\end{array}$ & 2007-present & Bay of Bengal & SSS, SST & $1000+$ \\
\hline ARGO buoys $^{37}$ & 2003-present & Global & SSS, SST & $1,000,000+$ \\
\hline $\mathrm{OOI}^{38}$ & 2014 onwards & Global (6 sites) & $\mathrm{pCO}_{2}$, SSS, SST, nitrate & New program \\
\hline SOCCOM $^{39}$ & 2014 onwards & Southern Ocean & SSS, SST, $\mathrm{pH}$, nitrate & New program \\
\hline
\end{tabular}

149

150 Table 1. In situ datasets and programs than can be used for the development and

151 validation of OA remote sensing algorithms.

152

153

154

155

156

157

158

159

160

161

162

163

164

165

\section{Potential of space based observations}

\subsection{Advantages and disadvantages}

While it has proven difficult to use remote sensing to directly monitor and detect changes in seawater $\mathrm{pH}$ and their impact on marine organisms ${ }^{22}$, satellites can measure sea surface temperature and salinity (SST and SSS) and surface chlorophyll-

a, from which carbonate system parameters can be estimated using empirical relationships derived from in situ data. Although surface measurements may not be representative of important biological processes, e.g. fish or shellfish, observations at the surface are particularly important for OA because the change in carbonate chemistry due to atmospheric $\mathrm{CO}_{2}$ occurs in the surface first. Thus satellites have great potential as a tool for assessing changes in carbonate chemistry. 
166 SST has been measured from space with infrared radiometry since the 1960s, but the

167 data are only globally of sufficient quality for climate studies since $1991^{40}$. Satellite

168 measurements of chlorophyll- $a$ in the visible are more recent, starting in 1986 and

169 delivering high quality global data since $1997^{41}$. Both measurements are made

170 globally at high spatial and temporal resolution, but with data gaps due to effects such

171 as cloud, which can greatly affect data availability in cloudy regions. SST is measured

172 in the top few microns, and chlorophyll-a is generally measured to depths around 1-

$173100 \mathrm{~m}$, depending on water clarity. Data quality can be affected by many issues, e.g.

174 adjacent land or ice may affect both SST and chlorophyll-a retrievals, and suspended

175 sediment may affect chlorophyll-a retrievals.

176

177 Only since 2009 has a satellite-based capability for measuring SSS existed. Increasing

178 salinity decreases the emissivity of seawater and so changes the microwave radiation

179 emitted at the water surface. ESA Soil Moisture and Ocean Salinity (SMOS) and

180 NASA-CONAE Aquarius (launched in 2009 and 2011 respectively, both currently in

181 operation), are L-band microwave sensors designed to detect variations in microwave

182 radiation and thus estimate ocean salinity in the top centimeter. The instruments are

183 novel and the measurement is very challenging, and research is ongoing to improve

184 data quality ${ }^{42}$. The instruments can measure every few days at a spatial resolution of

$18535-100 \mathrm{~km}$, but single measurements are very noisy, so the instantaneous swath data

186 are generally spatially and temporally averaged over 10 days or a month, with an

187 intended accuracy around $0.1-0.2 \mathrm{~g} / \mathrm{kg}$ for monthly $200 \mathrm{~km}$ data. A particular issue

188 close to urban areas is radio frequency interference from illegal broadcasts, which are

189 gradually being eliminated but still result in large data gaps, particularly for SMOS. 
190 The signal can be affected by nearby land or sea ice, and the sensitivity to SSS

191 decreases for cold water, by about $50 \%$ from $20^{\circ} \mathrm{C}$ to $0^{\circ} \mathrm{C}^{43}$.

192

193 With these challenges, a central question is whether satellite SSS can bring new

194 complementary information to in situ SSS measurements such as Argo for assessing

195 OA. Direct comparisons $\mathrm{s}^{44}, 45$ indicate differences of $0.15-0.5 \mathrm{~g} / \mathrm{kg}$ in a $1^{\circ} \mathrm{x} 1^{\circ}$ region

196 over 10-30 days. The two are difficult to compare directly however, as Argo measures

$1975 \mathrm{~m}$ or more from the surface, so some differences are expected even in the absence of

198 errors, especially where the water column is stratified. A better strategy might be to

199 compare their effectiveness in estimating OA. How the uncertainties propagate

200 through the carbonate system calculations is the subject of ongoing research.

202 Despite biases and uncertainties, satellite measurements of SSS in the top centimeter 203 contain geophysical information not detected by Argo 46, 47. In addition, Argo 204 coverage can be much poorer than satellite SSS in several regions such as the major 205 western boundary or equatorial currents and across strong oceanic fronts. The use of 206 interpolated Argo products presents an additional source of uncertainty due to the 207 interpolation scheme. ${ }^{48}$ Satellite SSS can also resolve mesoscale spatial structures not 208 resolved by Argo measurements ${ }^{49}$, and unlike Argo, satellites provide a synoptic 209 'snapshot' of a region at a given time.

211 Regular mapping of the SSS field with unprecedented temporal and spatial resolution 212 at global scale is now possible from satellites. The impact of using satellite SSS for 213 carbonate system algorithms can now be tested, where previously there was a reliance 214 on climatology, in situ or model data. For example, this provides the means to study 
215 the impact that freshwater influences (sea ice melt, riverine inputs and rain) can have

216 on the marine carbonate system. The use of satellite SSS data will also allow 217 evaluation of the impact on the carbonate system of the inter- and intra-annual 218 variations in SSS.

220 Recent advances in radar altimetry (e.g. Cryosat-2 and Sentinel 1 satellites and 221 sensors) are already enabling significant improvements in satellite sea-ice thickness 222 measurements ${ }^{50}$. Thin sea ice thickness can now also be determined from SMOS, 223 complementing altimeter estimates mostly valid for thick sea ice ${ }^{51}$. Sea ice thickness 224 is important for OA research as it indicates whether ice is seasonal or multi-year, 225 supporting the interpretation of carbonate parameters. Altimetry is also used to 226 measure wind speeds and increases the coverage of scatterometer estimates in polar 227 regions. It provides higher-resolution (along track) estimates of surface wind stress, 228 which can potentially be used to indicate regions of upwelling. Wind-driven 229 upwelling causes dense cooler water (with higher concentrations of $\mathrm{CO}_{2}$ and thus 230 more acidic) to be drawn up from depth to the ocean surface. This upwelling can have 231 significant impacts on local OA and ecosystems ${ }^{4,52}$, especially at eastern oceanic 232 boundaries ${ }^{53,54}$.

234 It is important to emphasise that the use of Earth observation data to derive carbonate 235 parameters should not be seen as a replacement for in situ measurement campaigns, 236 especially due to the current reliance on empirical and regional algorithms. Earth 237 observation algorithms need calibration and validation with in situ data such as those 238 taken by GOA-ON, and if the carbonate system response changes over time, empirical 239 and regional algorithms tuned to previous conditions may become less reliable. 


\subsection{Algorithms for estimating carbonate parameters}

243 The four key OA parameters $\left(\mathrm{pCO}_{2}, \mathrm{DIC}, \mathrm{TA}, \mathrm{pH}\right)$ are largely driven by temperature,

244 salinity and biological activity, allowing empirical relationships to be developed using 245 in situ measurements of OA parameters. Table 2 shows a range of published 246 algorithms based on such relationships, while Figure 1 shows their geographical 247 coverage. Both illustrate that most of the literature has focused on the northern basins 248 of the Pacific and Atlantic and the Arctic, especially the Barents Sea, with all other 249 regions only attracting algorithms for a single parameter or none at all.. ${ }^{55}$

\begin{tabular}{|c|c|c|}
\hline Parameter & Dependencies & Region and references \\
\hline \multirow{6}{*}{$\mathrm{pCO}_{2}$} & SST & Global $^{56}$, Barents Sea ${ }^{57}$ \\
\hline & SST, SSS & Barents Sea $^{58}$, Caribbean $^{14}$ \\
\hline & SST, Chl & N Pacific ${ }^{59}$ \\
\hline & SSS, Chl & North Sea ${ }^{60}$ \\
\hline & SST, SSS, Chl & $\mathrm{N}$ Pacific ${ }^{61}$ \\
\hline & SST, Chl, MLD & Barents Sea $^{62}$ \\
\hline \multirow{3}{*}{ TA } & SSS & Barents Sea $^{57}$ \\
\hline & SST, SSS & Global $^{18,63}$, Arctic $^{15}$ \\
\hline & SSS, nitrate & Global $^{55}$ \\
\hline \multirow{2}{*}{ DIC } & SST, SSS & Equatorial pacific $^{64}$ \\
\hline & SST, SSS, Chl & Arctic $^{15}$ \\
\hline $\mathrm{pH}$ & SST, Chl & N Pacific ${ }^{10}$ \\
\hline
\end{tabular}

252 Table 2. Example regional algorithms for each carbonate parameter illustrating the 253 variable dependencies. Chl is chlorophyll- $a$ and MLD is mixed layer depth. 


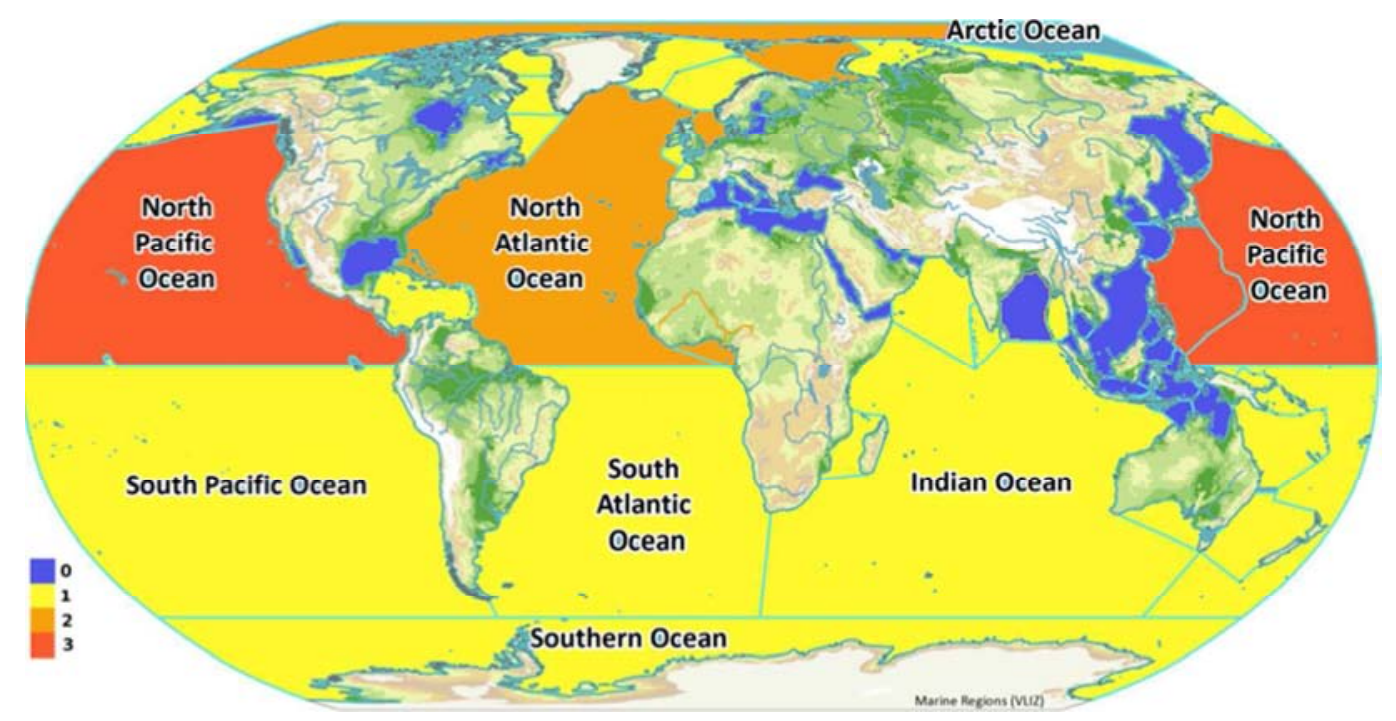

Figure 1. The number of key carbonate parameters $\left(f_{\mathrm{CO} 2}\right.$ or $\left.\mathrm{p}_{\mathrm{CO} 2}, \mathrm{TA}, \mathrm{DIC}, \mathrm{pH}\right)$ for which regional algorithms exist in the literature that can be implemented using just satellite Earth observation data. Regions are indicative of open ocean areas, as implementation of algorithms in coastal areas may be problematic.

256 NOAA's experimental Ocean Acidification Product Suite (OAPS) is a regional 257 example of using empirical algorithms with a combination of climatological SSS and 258 satellite SST to provide synoptic estimates of sea surface carbonate chemistry in the 259 Greater Caribbean Region ${ }^{14} \cdot \mathrm{p}_{\mathrm{CO} 2}$ and TA were derived from climatological SSS and 260 satellite SST, then used to calculate monthly estimates of the remaining carbonate 261 parameters, including aragonite saturation state and carbonate ion concentration. In 262 general the derived data were in good agreement with in situ measured data (e.g. 263 mean derived TA $=2375 \pm 36 \mu \mathrm{mol} \mathrm{kg}^{-1}$ compared to a mean ship-measured TA $=$

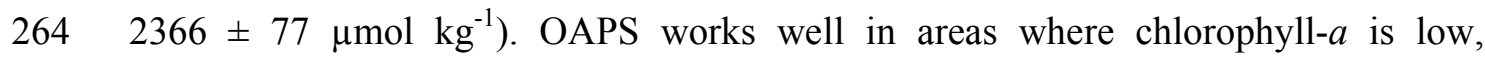
265 however in regions of high chlorophyll- $a$, where net productivity is likely to perturb 
266 the carbonate system, and in areas where there are river inputs, the approach tends to 267 underestimate aragonite saturation state, for example ${ }^{21}$.

269 A quite different approach is the assimilation of satellite data into ocean circulation 270 models ${ }^{65}$. The model output carbonate parameters can then be used directly. This 271 allows satellite-observed effects to be extended below the water surface, albeit with 272 the uncertainties inherent in model data. Here we seek to assess the direct use of 273 satellite data through empirical algorithms to improve OA estimates.

\section{Arctic Seas}

It is increasingly recognised that the Polar Oceans (Arctic and Antarctic) are

279 particularly sensitive to OA ${ }^{66}$. Lower alkalinity (and thus buffer capacity), enhanced 280 warming, reduced sea-ice cover resulting in changes in the freshwater budget ${ }^{67}$, and 281 nutrient limitation make it more vulnerable to future $\mathrm{OA}^{68}$. Retreating ice also 282 provides increased open water for air-sea gas exchange and primary production ${ }^{69}$.

284 The remote nature of the Arctic Ocean provides difficulties for collecting in situ 285 datasets, with limited ship, autonomous vehicle and buoy access, and in situ data 286 collection during winter months is often impossible. Therefore the use of remote 287 sensing techniques is very attractive, if sufficient in situ data can be found to calibrate 288 satellite algorithms, and if the challenges of Arctic remote sensing can be overcome. 289 These waters are very challenging regions for satellite remote sensing. For instance, 290 low water temperatures reduce the sensitivity range of SSS sensors ${ }^{43}$, and sea ice can 
291 complicate retrievals of SSS and chlorophyll- $a^{70,71}$. Improvement in the accuracy of 292 high latitude satellite SSS is expected soon by combining observations from SMOS, 293 Aquarius and the upcoming SMAP sensor, all polar-orbiting L-band radiometers.

\section{The Bay of Bengal}

296 This region is clearly a focus of current OA research with unique characteristics due 297 to the large freshwater influence. The flow of fresh water from the Ganges Delta into 298 Bay of Bengal $\left(42,000 \mathrm{~m}^{3} / \mathrm{sec}\right)$ represents the second greatest discharge source in the 299 world. Additionally, rainfall along with freshwater inputs exceeds evaporation, 300 resulting in net water gain annually in the Bay of Bengal. Collectively these provide 301 an annual positive water balance that reduces surface salinity by $3-7 \mathrm{~g} / \mathrm{kg}$ compared to 302 the adjacent Arabian Sea ${ }^{72,73}$, resulting in distinctly different biogeochemical regimes

$303{ }^{74}$. Biogeochemically, the Indian Ocean is one of the least studied and most poorly 304 understood ocean basins in the world ${ }^{74}$. This is particularly true for the Bay of Bengal 305 where a relatively small number of hydrographic sections and underway surface 306 observations have been undertaken, despite the notable influence of freshwater on 307 particle dynamics, air-sea carbon flux and surface carbonate chemistry ${ }^{75-79}$. North of $30815^{\circ} \mathrm{S}$, TA increases relative to salinity ${ }^{80}$, indicating the presence of an important land 309 source that can broadly affect acidification dynamics.

311 To date there is little work on acidification dynamics and air sea exchange of $\mathrm{CO}_{2}$ in 312 the Bay of Bengal ${ }^{81-83}$. In 2013, the Bay of Bengal Ocean Acidification (BOBOA) 313 Mooring was deployed for the first time in Bay of Bengal $\left(15^{\circ} \mathrm{N}, 90^{\circ} \mathrm{E}\right)$ by $\mathrm{PMEL}$ 314 (NOAA) and the Bay of Bengal Large Marine Ecosystem Program (BOBLME). Data 
315 from the buoy will improve our understanding of biogeochemical variations in the 316 open ocean environment of the Bay of Bengal.

318 It is an open question whether SSS can be used to estimate TA in the Bay of Bengal. 319 An important step towards answering this question would be to investigate the spatial 320 variability of the TA to salinity relationship in the region. Use of satellite SSS in the 321 region is also challenged by heavy radio frequency interference.

322

323

\section{The Greater Caribbean and the Amazon plume}

The reefs in the Greater Caribbean Region are economically important to the US and Caribbean nations with an estimated annual net value of US\$3.1-4.6 billion in $200{ }^{84}$. At least two thirds of these reefs are threatened from human impacts including OA. The skeleton of a coral is made of aragonite and the growth of their skeletons is reduced by $\mathrm{OA}^{6}$, and numerous studies have shown a net decline in coral calcification (growth) rates in accordance with declining $\mathrm{CaCO}_{3}$ saturation state ${ }^{85}$. The waters of the Greater Caribbean region are predominantly oligotrophic and similar to the subtropical gyre from which it receives most of its water ${ }^{14}$. Whilst the often shallow water environments of coral reefs and the plethora of small islands can make it challenging for Earth observation instruments to collect reliable data, the oligotrophic nature and the similarities in water type across the whole region make it ideal for the development of novel products. This region therefore provides an ideal case study to develop and evaluate algorithms representative of a shallow, oligotrophic environment. 
339 The Amazon plume, south of the Greater Caribbean, is the largest freshwater 340 discharge source in the world $\left(209,000 \mathrm{~m}^{3} / \mathrm{sec}\right)$. It can cause SSS decreases of several 341 units many hundreds of kilometers from land, and has an area that seasonally can 342 reach $10^{6} \mathrm{~km}^{2}$. These characteristics make it an ideal case study for testing and 343 evaluating remote sensing algorithms, particularly to study the space-time resolution 344 tradeoffs using SSS sensors.

345

346

\section{Future opportunities and focus}

The Copernicus program is a European flagship initiative, worth more than $€ 7$ billion, which aims to provide an operational satellite monitoring capability and related services for the environment and security ${ }^{86}$. The launch of the Sentinel-1A satellite in 2014 signaled its start. Of the five Sentinel satellite types, Sentinels 2 and 3 are most appropriate for assessment of the marine carbonate system ${ }^{87-89}$. These satellites will provide chlorophyll- $a$ and SST with unprecedented spatial and temporal coverage. The development of higher spatial resolution geostationary sensors that continually monitor chlorophyll- $a$ and SST over the same area of the Earth also holds much potential for the future of OA assessment and research ${ }^{90}$. These satellites and sensors are able to provide 10 or more observations per day, allowing the study of the effect of tidal and diurnal cycles on OA. The societal importance of measuring and observing the global carbon cycle was further highlighted with the launch of the NASA Orbiting Carbon Observatory (OCO-2) in 2014. This satellite and its sensors are designed to observe atmospheric $\mathrm{CO}_{2}$ concentrations, but its potential for marine carbon cycle and OA is likely to be a focus of future research. 
363 SMOS and Aquarius have recently passed their nominal lifetimes, with SMOS now

364 extended until 2017. Based on the lifetimes of previous satellite Earth observation 365 sensors, they may well operate until the early 2020s. NASA's SMAP satellite, to be 366 launched in January 2015, should provide short-term continuity. The development of 367 the technology and the clear importance of monitoring ocean salinity are likely to 368 support the development of future satellite sensors. Also, historical time series data 369 from alternative microwave sensors hold the potential for a $10+$ year time series of 370 satellite based SSS observations ${ }^{91}$, and this sort of measurement record is likely to 371 extend into the future as it forms the basis of a global SSS monitoring effort.

373 In summary, satellite products developed up to now in the OA context have been 374 regional, empirical or derived with a limited variety of satellite datasets, rendering an 375 effort to systematically exploit remote sensing assets (capitalizing on the recent 376 advent of satellite salinity measurements) absolutely timely. To-date there is only 377 regional application of satellite SST to address the issue of assessing OA ${ }^{62}$, along 378 with two non-peer-reviewed attempts to calculate carbonate system products using 379 satellite SSS data ${ }^{92,93}$. Supported by good in situ measurement campaigns, especially 380 in places with currently poor in situ coverage such as the Arctic, satellite 381 measurements are likely to become a key element in understanding and assessing OA.

\section{AUTHOR INFORMATION}

384 Corresponding Author

385 *Peter Land, peland@pml.ac.uk

\section{Author Contributions}


387 The manuscript was written through contributions of all authors. All authors have

388 given approval to the final version of the manuscript.

\section{$390 \quad$ Funding Sources}

391 This work was funded by the European Space Agency Support to Science Element

392 Pathfinders Ocean Acidification project (contract No. 4000110778/14/I-BG).

\section{ACKNOWLEDGMENT}

395 This work was enabled by European Space Agency (ESA) Support to Science

396 Element (STSE) Pathfinders Ocean Acidification project (contract No.

$3974000110778 / 14 / \mathrm{I}-\mathrm{BG})$. The authors gratefully acknowledge the assistance of Diego

398 Fernandez (STSE programme manager).

\section{BIOGRAPHICAL STATEMENT}

401 Peter Land is a remote sensing scientist at Plymouth Marine Laboratory (PML), 402 specializing in atmosphere-ocean gas exchange and carbonate chemistry. Jamie 403 Shutler is an oceanographer and former European Space Agency (ESA) fellow 404 specializing in atmosphere-ocean gas exchange at the University of Exeter. Helen 405 Findlay is an oceanographer at PML specializing in ocean acidification and carbonate 406 chemistry. Fanny Girard-Ardhuin is a remote sensing scientist specializing in sea ice 407 at l'Institut Français de Recherche pour l'Exploitation de la Mer (Ifremer). Nicolas 408 Reul is a remote sensing scientist at Ifremer and member of the SMOS scientific 409 team. Jean-Francois Piolle is a computer scientist at Ifremer. Bertrand Chapron leads 410 remote sensing research at Ifremer. Yves Quilfen is an altimetry remote sensing 
411 scientist at Ifremer. Joseph Salisbury and Douglas Vandemark are oceanographers at

412 the University of New Hampshire focusing on biogeochemistry and ecology in coastal

413 areas. Richard Bellerby is a chemical oceanographer at the Norwegian Institute for

414 Water Research, a member of the GOA-ON executive committee, and leader of the

415 AMAP and SCAR ocean acidification working groups. Punyasloke Bhadury is a

416 coastal ecologist at the Indian Institute of Science Education and Research-Kolkata.

417 Roberto Sabia is a specialist in remote sensing of salinity working for ESA.

\section{REFERENCES}

420 1. IPCC Working Group I Contribution to the IPCC Fifth Assessment Report, 421 Climate Change 2013: The Physical Science Basis, Summary for Policymakers. 422 http://www.ipcc.ch/report/ar5/wg1/ - .U17CrUpwbos

423 2. Fabry, V. J.; Seibel, B. A.; Feely, R. A.; Orr, J. C., Impacts of ocean 424 acidification on marine fauna and ecosystem processes. ICES Journal of Marine 425 Science: Journal du Conseil 2008, 65, (3), 414-432.

426 3. Turley, C.; Eby, M.; Ridgwell, A. J.; Schmidt, D. N.; Findlay, H. S.; 427 Brownlee, C.; Riebesell, U.; Fabry, V. J.; Feely, R. A.; Gattuso, J. P., The societal 428 challenge of ocean acidification. Marine Pollution Bulletin 2010, 60, (6), 787-792.

429 4. Feely, R. A.; Sabine, C. L.; Hernandez-Ayon, J. M.; Ianson, D.; Hales, B., 430 Evidence for upwelling of corrosive" acidified" water onto the continental shelf. 431 Science 2008, 320, (5882), 1490-1492.

$432 \quad 5 . \quad$ Bellerby, R. G. J. UN biodiversity and OA report. http://www.cbd.int/ts

433 6. Kroeker, K. J.; Kordas, R. L.; Crim, R.; Hendriks, I. E.; Ramajo, L.; Singh, G. 434 S.; Duarte, C. M.; Gattuso, J. P., Impacts of ocean acidification on marine organisms: 435 quantifying sensitivities and interaction with warming. Global Change Biology 2013.

436 7. Salisbury, J.; Green, M.; Hunt, C.; Campbell, J., Coastal acidification by 437 rivers: a threat to shellfish? Eos, Transactions American Geophysical Union 2008, 89, 438 (50), 513.

439 8. Widdicombe, S.; Spicer, J. I., Predicting the impact of ocean acidification on 440 benthic biodiversity: what can animal physiology tell us? Journal of Experimental 441 Marine Biology and Ecology 2008, 366, (1), 187-197.

442 9. Ridgwell, A.; Schmidt, D. N.; Turley, C.; Brownlee, C.; Maldonado, M. T.; 443 Tortell, P.; Young, J. R., From laboratory manipulations to Earth system models: 444 scaling calcification impacts of ocean acidification. Biogeosciences 2009, 6, (11), $445 \quad 2611-2623$.

446 10. Nakano, Y.; Watanabe, Y. W., Reconstruction of $\mathrm{pH}$ in the surface seawater 447 over the north Pacific basin for all seasons using temperature and chlorophyll-a. 448 Journal of oceanography 2005, 61, (4), 673-680.

449 11. Juranek, L. W.; Feely, R. A.; Peterson, W. T.; Alin, S. R.; Hales, B.; Lee, K.; 450 Sabine, C. L.; Peterson, J., A novel method for determination of aragonite saturation 
451 state on the continental shelf of central Oregon using multi-parameter relationships 452 with hydrographic data. Geophysical Research Letters 2009, 36, (24), L24601.

453 12. Midorikawa, T.; Inoue, H. Y.; Ishii, M.; Sasano, D.; Kosugi, N.; Hashida, G.; 454 Nakaoka, S.-i.; Suzuki, T., Decreasing pH trend estimated from 35-year time series of carbonate parameters in the Pacific sector of the Southern Ocean in summer. Deep Sea Research Part I: Oceanographic Research Papers 2012, 61, 131-139. 13. Bostock, H. C.; Mikaloff Fletcher, S. E.; Williams, M. J. M., Estimating carbonate parameters from hydrographic data for the intermediate and deep waters of the Southern Hemisphere Oceans. Biogeosciences Discussions 2013, 10, (4), 62256257.

14. Gledhill, D. K.; Wanninkhof, R.; Millero, F. J.; Eakin, M., Ocean acidification of the greater Caribbean region 1996-2006. Journal of Geophysical research 2008, 113, (C10), C10031.

15. Arrigo, K. R.; Pabi, S.; van Dijken, G. L.; Maslowski, W., Air-sea flux of CO2 in the Arctic Ocean, 1998-2003. J. Geophys. Res 2010, 115, (G4), G04024.

16. Dickson, A. G.; Goyet, C., Handbook of methods for the analysis of the various parameters of the carbon dioxide system in sea water. Version: 1992; Vol. 2. 17. Weiss, R. F., Carbon dioxide in water and seawater: the solubility of a nonideal gas. Mar. Chem 1974, 2, (3), 203-215.

18. Lee, K.; Tong, L. T.; Millero, F. J.; Sabine, C. L.; Dickson, A. G.; Goyet, C.; Park, G. H.; Wanninkhof, R.; Feely, R. A.; Key, R. M., Global relationships of total alkalinity with salinity and temperature in surface waters of the world's oceans. Geophysical Research Letters 2006, 33, (19).

19. Smith, S. V.; Key, G. S., Carbon dioxide and metabolism in marine environments. Limnol. Oceanogr 1975, 20, (3), 493-495.

20. Sarmiento, J. L.; Gruber, N., Ocean biogeochemical dynamics. Cambridge Univ Press: 2006; Vol. 503.

21. Gledhill, D. K.; Wanninkhof, R.; Eakin, C. M., Observing ocean acidification from space. Oceanography 2009, 22.

22. Sun, Q.; Tang, D.; Wang, S., Remote-sensing observations relevant to ocean acidification. International Journal of Remote Sensing 2012, 33, (23), 7542-7558.

23. Dickson, A. G., The carbon dioxide system in seawater: equilibrium chemistry and measurements. In Guide to best practices for ocean acidification research and data reporting, Riebesell, U.; Fabry, C. J.; Hansson, L.; Gattuso, J.-P., Eds. European Commission: Brussels, 2011; pp 17-40.

24. Dickson, A. G.; Sabine, C. L.; Christian, J. R., Guide to best practices for ocean $\mathrm{CO} 2$ measurements. 2007.

25. Byrne, R. H., Measuring Ocean Acidification: New Technology for a New Era of Ocean Chemistry. Environmental science \& technology 2014, 48, (10), 5352-5360.

26. Martz, T. R.; Connery, J. G.; Johnson, K. S., Testing the Honeywell Durafet $\mathbb{}$ for seawater $\mathrm{pH}$ applications. Limnol Oceanogr Methods 2010, 8, 172-184.

27. Bakker, D. C. E.; Hankin, S.; Olsen, A.; Pfeil, B.; Smith, K.; Alin, S. R.; Cosca, C.; Hales, B.; Harasawa, S.; Kozyr, A., An update to the Surface Ocean CO2 Atlas (SOCAT version 2). Earth System Science Data 2014.

28. Takahashi, T.; Sutherland, S. C.; Kozyr, A. Global Ocean Surface Water Partial Pressure of CO2 Database: Measurements Performed During 1957-2012 (Version 2012); ORNL/CDIAC-160, NDP-088(V2012); Carbon Dioxide Information Analysis Center, Oak Ridge National Laboratory, U.S. Department of Energy: Oak Ridge, Tennessee, USA, 2013. 
500 29. Key, R. M.; Kozyr, A.; Sabine, C. L.; Lee, K.; Wanninkhof, R.; Bullister, J. 501 L.; Feely, R. A.; Millero, F. J.; Mordy, C.; Peng, T. H., A global ocean carbon 502 climatology: Results from Global Data Analysis Project (GLODAP). Global 503 Biogeochemical Cycles 2004, 18, (4).

504 30. CARINA group Carbon in the Arctic Mediterranean Seas Region - the 505 CARINA project: Results and Data, Version 1.2.; Carbon Dioxide Information 506 Analysis Center, Oak Ridge National Laboratory, U.S. Department of Energy: Oak 507 Ridge, Tennessee, USA, 2009.

508 31. CARINA group Carbon in the Atlantic Ocean Region - the CARINA project: 509 Results and Data, Version 1.0.; Carbon Dioxide Information Analysis Center, Oak 510 Ridge National Laboratory, U.S. Department of Energy: Oak Ridge, Tennessee, USA, 5112009.

512 32. CARINA group Carbon in the Southern Ocean Region - the CARINA project: 513 Results and Data, Version 1.1.; Carbon Dioxide Information Analysis Center, Oak 514 Ridge National Laboratory, U.S. Department of Energy: Oak Ridge, Tennessee, USA, 5152010.

516 33. Robinson, C.; Holligan, P.; Jickells, T.; Lavender, S., The Atlantic Meridional 517 Transect Programme (1995-2012). Deep Sea Research Part II: Topical Studies in 518 Oceanography 2009, 56, (15), 895-898.

519 34. Yakushev, E. V.; Sørensen, K., On seasonal changes of the carbonate system 520 in the Barents Sea: observations and modeling. Marine Biology Research 2013, 9, (9), $521 \quad 822-830$.

$522 \quad 35 . \quad$ Skjelvan, I.; Falck, E.; Rey, F.; Kringstad, S. B., Inorganic carbon time series 523 at Ocean Weather Station M in the Norwegian Sea. Biogeosciences 2008, 5, 549-560.

524 36. McPhaden, M. J.; Meyers, G.; Ando, K.; Masumoto, Y.; Murty, V. S. N.; 525 Ravichandran, M.; Syamsudin, F.; Vialard, J.; Yu, L.; Yu, W., RAMA: The research 526 moored array for African-Asian-Australian monsoon analysis and prediction. 2009.

527 37. ARGO Argo - part of the integrated global observation strategy. 528 http://www.argo.ucsd.edu (14/12/2014),

529 38. OOI Ocean Observatories Initiative. http://oceanobservatories.org $(14 / 12 / 2014)$,

39. SOCCOM SOUTHERN OCEAN CARBON AND CLIMATE OBSERVATIONS AND MODELING. http://soccom.princeton.edu (14/12/2014), 40. Merchant, C. J.; Embury, O.; Rayner, N. A.; Berry, D. I.; Corlett, G. K.; Lean, K.; Veal, K. L.; Kent, E. C.; Llewellyn $\square$ Jones, D. T.; Remedios, J. J., A 20 year independent record of sea surface temperature for climate from Along $\square$ Track Scanning Radiometers. Journal of Geophysical Research: Oceans (1978-2012) 2012, 117, (C12).

41. McClain, C. R.; Feldman, G. C.; Hooker, S. B., An overview of the SeaWiFS project and strategies for producing a climate research quality global ocean biooptical time series. Deep Sea Research Part II: Topical Studies in Oceanography 2004, 51, (1), 5-42.

42. Font, J.; Boutin, J.; Reul, N.; Spurgeon, P.; Ballabrera-Poy, J.; Chuprin, A.; Gabarró, C.; Gourrion, J.; Guimbard, S.; Hénocq, C., SMOS first data analysis for sea surface salinity determination. International Journal of Remote Sensing 2013, 34, (910), 3654-3670.

43. Font, J.; Camps, A.; Borges, A.; Martín-Neira, M.; Boutin, J.; Reul, N.; Kerr, Y. H.; Hahne, A.; Mecklenburg, S., SMOS: The challenging sea surface salinity measurement from space. Proceedings of the IEEE 2010, 98, (5), 649-665. 
44. Boutin, J.; Martin, N.; Reverdin, G.; Morisset, S.; Yin, X.; Centurioni, L.; Reul, N., Sea surface salinity under rain cells: SMOS satellite and in situ drifters observations. Journal of Geophysical Research: Oceans 2014, 119, (8), 5533-5545.

45. Reul, N.; Chapron, B.; Lee, T.; Donlon, C.; Boutin, J.; Alory, G., Sea surface salinity structure of the meandering Gulf Stream revealed by SMOS sensor. Geophysical Research Letters 2014, 41, (9), 3141-3148.

46. Boutin, J.; Martin, N.; Reverdin, G.; Yin, X.; Gaillard, F., Sea surface freshening inferred from SMOS and ARGO salinity: impact of rain. Ocean Science 2013, 9, 183-192.

47. Sabia, R.; Klockmann, M.; Fernández $\square$ Prieto, D.; Donlon, C., A first estimation of SMOS $\square$ based ocean surface $\mathrm{T} \square \mathrm{S}$ diagrams. Journal of Geophysical Research: Oceans 2014, 119, (10), 7357-7371.

48. Hosoda, S.; Ohira, T.; Nakamura, T., A monthly mean dataset of global oceanic temperature and salinity derived from Argo float observations. JAMSTEC Report of Research and Development 2008, 8, 47-59.

49. Reul, N.; Fournier, S.; Boutin, J.; Hernandez, O.; Maes, C.; Chapron, B.; Alory, G.; Quilfen, Y.; Tenerelli, J.; Morisset, S., Sea surface salinity observations from space with the SMOS satellite: a new means to monitor the marine branch of the water cycle. Surveys in Geophysics 2014, 35, (3), 681-722.

50. Laxon, S. W.; Giles, K. A.; Ridout, A. L.; Wingham, D. J.; Willatt, R.; Cullen, R.; Kwok, R.; Schweiger, A.; Zhang, J.; Haas, C., CryoSat $\square 2$ estimates of Arctic sea ice thickness and volume. Geophysical Research Letters 2013, 40, (4), 732-737.

51. Kaleschke, L.; Tian $\square$ Kunze, X.; Maaß, N.; Mäkynen, M.; Drusch, M., Sea ice thickness retrieval from SMOS brightness temperatures during the Arctic freeze $\square$ up period. Geophysical Research Letters 2012, 39, (5).

52. Mathis, J. T.; Pickart, R. S.; Byrne, R. H.; McNeil, C. L.; Moore, G. W. K.; Juranek, L. W.; Liu, X.; Ma, J.; Easley, R. A.; Elliot, M. M., Storm $\square$ induced upwelling of high pCO2 waters onto the continental shelf of the western Arctic Ocean and implications for carbonate mineral saturation states. Geophysical Research Letters 2012, 39, (7). 53. Mahadevan, A.; Tagliabue, A.; Bopp, L.; Lenton, A.; Memery, L.; Lévy, M., Impact of episodic vertical fluxes on sea surface pCO2. Philosophical Transactions of the Royal Society A: Mathematical, Physical and Engineering Sciences 2011, 369, (1943), 2009-2025.

54. Mahadevan, A., Ocean science: Eddy effects on biogeochemistry. Nature 2014.

55. Takahashi, T.; Sutherland, S. Climatological mean distribution of $\mathrm{pH}$ and carbonate ion concentration in Global Ocean surface waters in the Unified pH scale and mean rate of their changes in selected areas; OCE 10-38891; National Science Foundation: Washington, D. C., USA, 2013.

56. Goddijn-Murphy, L. M.; Woolf, D. K.; Land, P. E.; Shutler, J. D.; Donlon, C., Deriving a sea surface climatology of $\mathrm{CO} 2$ fugacity in support of air-sea gas flux studies. Ocean Science Discussions 2014, 11, 1895-1948.

57. Årthun, M.; Bellerby, R. G. J.; Omar, A. M.; Schrum, C., Spatiotemporal variability of air-sea $\mathrm{CO}<\mathrm{sub}>2</$ sub $>$ fluxes in the Barents Sea, as determined from empirical relationships and modeled hydrography. Journal of Marine Systems 2012, $98,40-50$.

58. Friedrich, T.; Oschlies, A., Basin $\square$ scale pCO2 maps estimated from ARGO float data: A model study. Journal of Geophysical Research: Oceans (1978-2012) 2009, 114, (C10). 
599 59. Ono, T.; Saino, T.; Kurita, N.; Sasaki, K., Basin-scale extrapolation of 600 shipboard pCO2 data by using satellite SST and Chla. International Journal of 601 Remote Sensing 2004, 25, (19), 3803-3815.

602 60. Borges, A. V.; Ruddick, K.; Lacroix, G.; Nechad, B.; Asteroca, R.; Rousseau, 603 V.; Harlay, J., Estimating pCO2 from remote sensing in the Belgian coastal zone. ESA 604 Special Publications 2010, 686.

605 61. Sarma, V. V. S. S.; Saino, T.; Sasaoka, K.; Nojiri, Y.; Ono, T.; Ishii, M.; 606 Inoue, H. Y.; Matsumoto, K., Basin $\square$ scale pCO2 distribution using satellite sea 607 surface temperature, $\mathrm{Chl}$ a, and climatological salinity in the North Pacific in spring 608 and summer. Global Biogeochemical Cycles 2006, 20, (3).

609 62. Lauvset, S. K.; Chierici, M.; Counillon, F.; Omar, A.; Nondal, G.; 610 Johannessen, T.; Olsen, A., Annual and seasonal fCO2 and air-sea CO2 fluxes in the 611 Barents Sea. Journal of Marine Systems 2013.

612 63. Millero, F. J.; Lee, K.; Roche, M., Distribution of alkalinity in the surface 613 waters of the major oceans. Marine Chemistry 1998, 60, (1), 111-130.

614 64. Loukos, H.; Vivier, F.; Murphy, P. P.; Harrison, D. E.; Le Quéré, C., 615 Interannual variability of equatorial Pacific CO2 fluxes estimated from temperature 616 and salinity data. Geophysical Research Letters 2000, 27, (12), 1735-1738.

617 65. Anderson, D.; Sheinbaum, J.; Haines, K., Data assimilation in ocean models. 618 Reports on Progress in Physics 1996, 59, (10), 1209.

619 66. Steinacher, M.; Joos, F.; Frölicher, T. L.; Plattner, G. K.; Doney, S. C., 620 Imminent ocean acidification in the Arctic projected with the NCAR global coupled 621 carbon cycle-climate model. Biogeosciences 2009, 6, (4), 515-533.

622 67. Peterson, B. J.; Holmes, R. M.; McClelland, J. W.; Vörösmarty, C. J.; 623 Lammers, R. B.; Shiklomanov, A. I.; Shiklomanov, I. A.; Rahmstorf, S., Increasing 624 river discharge to the Arctic Ocean. Science 2002, 298, (5601), 2171-2173.

625 68. Shadwick, E. H.; Trull, T. W.; Thomas, H.; Gibson, J. A. E., Vulnerability of 626 Polar Oceans to Anthropogenic Acidification: Comparison of Arctic and Antarctic 627 Seasonal Cycles. Sci. Rep. 2013, 3.

628 69. McGuire, A. D.; Anderson, L. G.; Christensen, T. R.; Dallimore, S.; Guo, L.; 629 Hayes, D. J.; Heimann, M.; Lorenson, T. D.; Macdonald, R. W.; Roulet, N., 630 Sensitivity of the carbon cycle in the Arctic to climate change. Ecological 631 Monographs 2009, 79, (4), 523-555.

632 70. Zine, S.; Boutin, J.; Font, J.; Reul, N.; Waldteufel, P.; Gabarró, C.; Tenerelli, 633 J.; Petitcolin, F.; Vergely, J. L.; Talone, M., Overview of the SMOS sea surface 634 salinity prototype processor. Geoscience and Remote Sensing, IEEE Transactions on $6352008,46,(3), 621-645$.

636 71. Bélanger, S.; Ehn, J. K.; Babin, M., Impact of sea ice on the retrieval of water637 leaving reflectance, chlorophyll $<\mathrm{i}>\mathrm{a}</ \mathrm{i}>$ concentration and inherent optical 638 properties from satellite ocean color data. Remote Sensing of Environment 2007, 111, 639 (1), 51-68.

640 72. Varkey, M. J.; Murty, V. S. N.; Suryanarayana, A., Physical oceanography of 641 the Bay of Bengal and Andaman Sea. Oceanography and marine biology: an annual 642 review 1996, 34, 1-70p.

643 73. Vinayachandran, P. N.; Murty, V. S. N.; Ramesh Babu, V., Observations of 644 barrier layer formation in the Bay of Bengal during summer monsoon. Journal of 645 Geophysical Research: Oceans (1978-2012) 2002, 107, (C12), SRF-19.

646 74. International CLIVAR Project Office Understanding The Role Of The Indian 647 Ocean In The Climate System - Implementation Plan For Sustained Observations; 648 International CLIVAR Project Office: 2006. 
649 75. Sarma, V. V. S. S.; Krishna, M. S.; Rao, V. D.; Viswanadham, R.; Kumar, N. 650 A.; Kumari, T. R.; Gawade, L.; Ghatkar, S.; Tari, A., Sources and sinks of CO2 in the 651 west coast of Bay of Bengal. Tellus B 2012, 64, 10961.

652 76. Madhupratap, M.; Gauns, M.; Ramaiah, N.; Prasanna Kumar, S.; 653 Muraleedharan, P. M.; De Sousa, S. N.; Sardessai, S.; Muraleedharan, U., 654 Biogeochemistry of the Bay of Bengal: physical, chemical and primary productivity 655 characteristics of the central and western Bay of Bengal during summer monsoon 656 2001. Deep Sea Research Part II: Topical Studies in Oceanography 2003, 50, (5), $657881-896$.

658 77. Ittekkot, V.; Nair, R. R.; Honjo, S.; Ramaswamy, V.; Bartsch, M.; Manganini, 659 S.; Desai, B. N., Enhanced particle fluxes in Bay of Bengal induced by injection of 660 fresh water. Nature 1991, 351, (6325), 385-387.

661 78. Ramaswamy, V.; Nair, R. R., Fluxes of material in the Arabian Sea and Bay of 662 Bengal-Sediment trap studies. Proceedings of the Indian Academy of Sciences-Earth 663 and Planetary Sciences 1994, 103, (2), 189-210.

664 79. Gomes, H. R.; Goes, J. I.; Saino, T., Influence of physical processes and 665 freshwater discharge on the seasonality of phytoplankton regime in the Bay of 666 Bengal. Continental Shelf Research 2000, 20, (3), 313-330.

667 80. Sabine, C. L.; Key, R. M.; Feely, R. A.; Greeley, D., Inorganic carbon in the 668 Indian Ocean: Distribution and dissolution processes. Global Biogeochemical Cycles 669 2002, 16, (4), 1067.

670 81. Biswas, H.; Mukhopadhyay, S. K.; De, T. K.; Sen, S.; Jana, T. K., Biogenic 671 controls on the air-water carbon dioxide exchange in the Sundarban mangrove 672 environment, northeast coast of Bay of Bengal, India. Limnology and Oceanography 673 2004, 49, (1), 95-101.

674 82. PrasannaKumar, S.; Sardessai, S.; Ramaiah, N.; Bhosle, N. B.; Ramaswamy, 675 V.; Ramesh, R.; Sharada, M. K.; Sarin, M. M.; Sarupria, J. S.; Muraleedharan, U. Bay 676 of Bengal Process Studies Final Report; NIO: Goa, India, 2006; p 141.

677 83. Akhand, A.; Chanda, A.; Dutta, S.; Manna, S.; Hazra, S.; Mitra, D.; Rao, K. 678 H.; Dadhwal, V. K., Characterizing air-sea CO2 exchange dynamics during winter in 679 the coastal water off the Hugli-Matla estuarine system in the northern Bay of Bengal, 680 India. Journal of oceanography 2013, 69, (6), 687-697.

681 84. Burke, L. M.; Maidens, J., Reefs at Risk in the Caribbean. World Resources 682 Institute Washington, DC: 2004.

683 85. Langdon, C.; Atkinson, M. J., Effect of elevated pCO2 on photosynthesis and 684 calcification of corals and interactions with seasonal change in temperature/irradiance 685 and nutrient enrichment. Journal of Geophysical Research: Oceans (1978-2012) 686 2005, 110, (C9).

687 86. Aschbacher, J.; Milagro-Pérez, M. P., The European Earth monitoring 688 (GMES) programme: Status and perspectives. Remote Sensing of Environment 2012, 689 120,3-8.

690 87. Berger, M.; Moreno, J.; Johannessen, J. A.; Levelt, P. F.; Hanssen, R. F., 691 ESA's sentinel missions in support of Earth system science. Remote Sensing of 692 Environment 2012, 120, 84-90.

693 88. Drusch, M.; Del Bello, U.; Carlier, S.; Colin, O.; Fernandez, V.; Gascon, F.; 694 Hoersch, B.; Isola, C.; Laberinti, P.; Martimort, P., Sentinel-2: ESA's optical high695 resolution mission for GMES operational services. Remote Sensing of Environment 696 2012, 120, 25-36.

697 89. Donlon, C.; Berruti, B.; Buongiorno, A.; Ferreira, M. H.; Féménias, P.; 698 Frerick, J.; Goryl, P.; Klein, U.; Laur, H.; Mavrocordatos, C., The global monitoring 
699 for environment and security (GMES) sentinel-3 mission. Remote Sensing of 700 Environment 2012, 120, 37-57.

701 90. IOCCG http://www.ioccg.org/sensors/GOCI.html (27 August 2014),

702 91. Reul, N.; Saux $\square$ Picart, S.; Chapron, B.; Vandemark, D.; Tournadre, J.; 703 Salisbury, J., Demonstration of ocean surface salinity microwave measurements from 704 space using AMSR $\square$ E data over the Amazon plume. Geophysical Research Letters 705 2009, 36, (13).

706 92. Sabia, R.; Fernández-Prieto, D.; Donlon, C.; Shutler, J.; Reul, N. In $A$ 707 preliminary attempt to estimate surface ocean $p H$ from satellite observations, IMBER 708 Open Science Conference, Bergen, Norway, 2014; Bergen, Norway, 2014.

709 93. Willey, D. A.; Fine, R. A.; Millero, F. J., Global surface alkalinity from 710 Aquarius satellite. In Ocean Sciences Meeting, Honolulu, Hawaii, USA, 2014. 


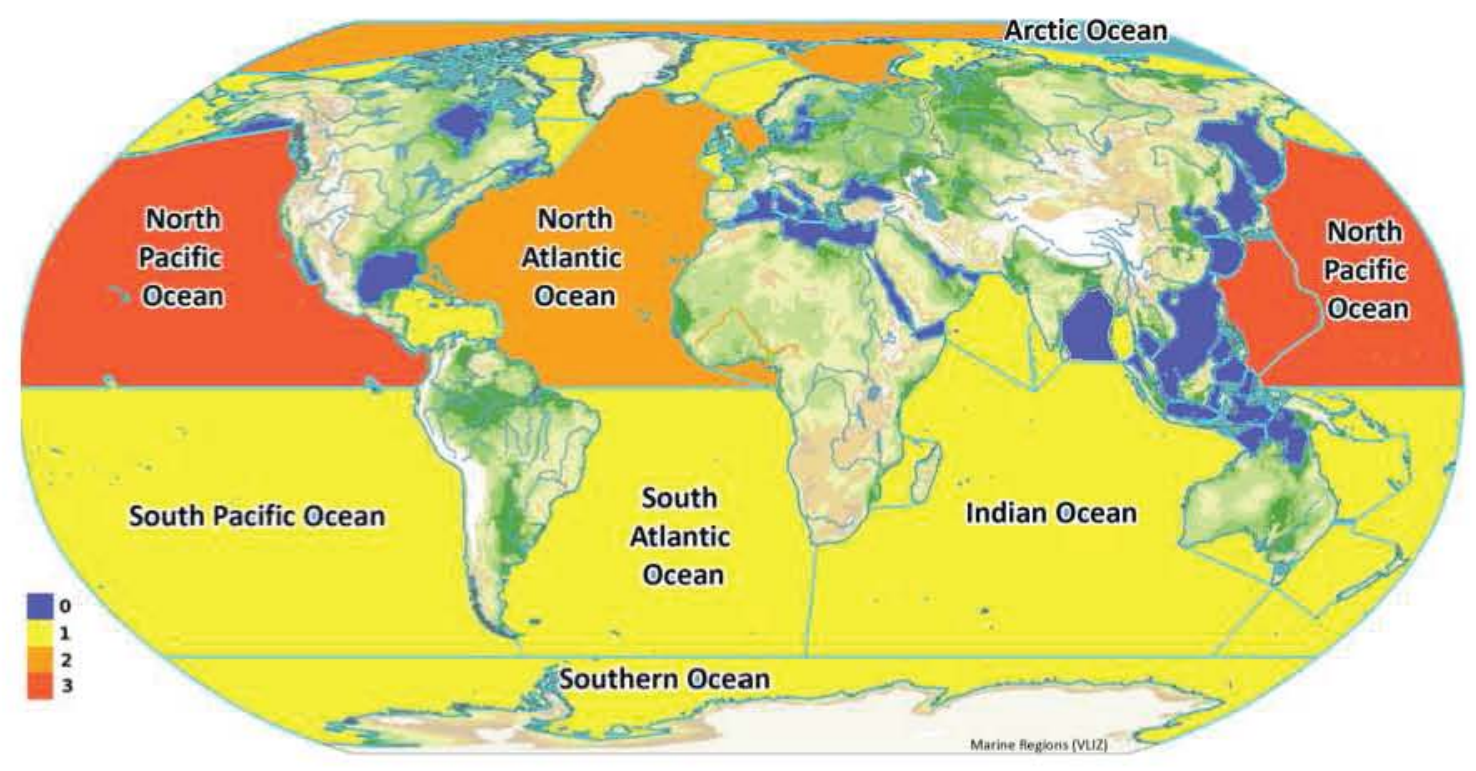

